Oksana Davydova,

Doctor of Economics, Professor, Kharkov State University of Food Technology and Trade, 333, Klochkovskaya str., Kharkiv, 61051, Ukraine, ORCID: 0000-0003-3045-9464;

ResearcherID: AAA-2501-2020

Kseniia Kalienik, Ph.D. in Economics, Kharkov State University of Food Technology and Trade, 333, Klochkovskaya str., Kharkiv, 61051, Ukraine, ORCID: 0000-0002-1219-2404; ResearcherID: V4138-2017

\title{
THEORETICAL -METHODOLOGICAL FOUNDATIONS OF TOURISM DEVELOPMENT: WORLD AND NATIONAL ASPECTS
}

The article presents the results of studies of tourist flows by purpose of stay, by type of transportation. The factors of development of tourist industry of Ukraine have been studied. The analysis of the tourism industry on the basis of world ratings and indices made it possible to determine Ukraine's place in the ranking. Ukraine's rating on the competitiveness of the tourism industry in 2019 is low and in need to be concentrated on its growth.

Keywords: tourist industry, travel, competitiveness, development.

Relevance of research topic. Tourism is one of the most dynamic industries of the XXI century, which is rapidly developing and facilitating the activation of activities in many related industries, contributing to the economic development of countries and regions. In the modern globalized world, the tourism industry is gaining ground and generating more revenue.

Driven by a relatively strong global economy, a growing middle class in emerging economies, technological advances, new business models, affordable travel costs and visa facilitation, international tourist arrivals grew 5\% in 2018 to reach the 1,4 billion mark. This figure was reached two years ahead of UNWTO forecast. At the same time, export earnings generated by tourism have grown to USD 1,7 trillion. This makes the sector a true global force for economic growth and development, driving the creation of more and better jobs and serving as catalyst for innovation and entrepreneurship. Tourism is helping build better lives for millions of individuals and transforming whole communities [10]. 
Growth in international tourist arrivals and receipts continues to outpace the world economy and both emerging and advanced economies are benefiting from rising tourism income. For the seventh year in a row, tourism exports grew faster than merchandise exports, reducing trade deficits in many countries. With such growth comes more responsibility in ensuring effective destination management that minimizes any adverse effect of tourism.

Formulation of the problem. Managing tourism in a sustainable manner for the benefit of all is more critical than ever. Growth in international tourist arrivals need to grow more in value rather than just in volume. Digitalization, innovation, greater accessibility and societal changes are expected to continue shaping our sector. Both destinations and companies will need to adapt to remain competitive, while at the same time embracing tourism as a means of achieving the Sustainable Development Goals and building a better future for all. Therefore, it is necessary to study the current state of development of tourism in the world and in Ukraine, as well as to determine the degree of competitiveness of tourism in the countries of the world and to determine the place of Ukraine in this rating.

Analysis of recent research and publications. The peculiarities of the development of the tourist industry of Ukraine were investigated in the works of N. I. Babin, H. O. Voroshylovoi, N. P. Hostievoi, S. M. Vasylchenka, V. P. Hrechanyka, O. M. Kalchenko, I. V. Svydy, L. V. Kharchenko; O. O. Yastremskoi, L. V. Martseniuk, A. A. Terebukha, O. S. Trehubova, O. P. Makara, A. Yu. Parfinenka, B. V. Shupika, N. F. Aleksieieva, L. M. Sakun etc.

Results of researches of scientists attest the increase of competitiveness of national tourist industry, but the analysis of a condition of tourist industry in Ukraine in comparison with world leaders is not presented recently in researches.

Presenting main material. Among the strong economy drive tourism growth should be noted:

- favourable economic environment (in 2018 World GDP increased by 3,6\%; exchange rate movements generally moderate; low interest rates);

- strong demand for air travel (the increased by $6 \%$ in international passenger traffic measured in revenue passenger kilometres (RPKs) according to IATA; stable fuel prices and lower fares (fares at $-60 \%$ vs 1998); over the past two decades, the number of unique city pairs connected by air transport has more than doubled, reaching more than 20,000 at ever lower costs);

- digital technologies are shaping traveller's experience (Artificial Intelligence is transforming tourism, from virtual assistants to companies being able to offer hyper-personalized customer experiences and improve business performance; an increasing number of destinations are measuring tourism in real time for a better management of visitor flows);

- enhanced visa facilitation (eVisas and visas on arrival on the rise while traditional visas are decreasing; the share of world population requiring a traditional 
visa declined from $75 \%$ in 1980 to $53 \%$ in 2018 ; however, half of the world population still needed a traditional visa in 2018) [10].

Leisure travel is the main purpose of visit in all world regions except the Middle East, where visiting friends and relatives (VFR), or for health or religious purposes predominates. The share of leisure travel has grown from 50\% in 2000 to $56 \%$ in 2018 (figure 1.1).

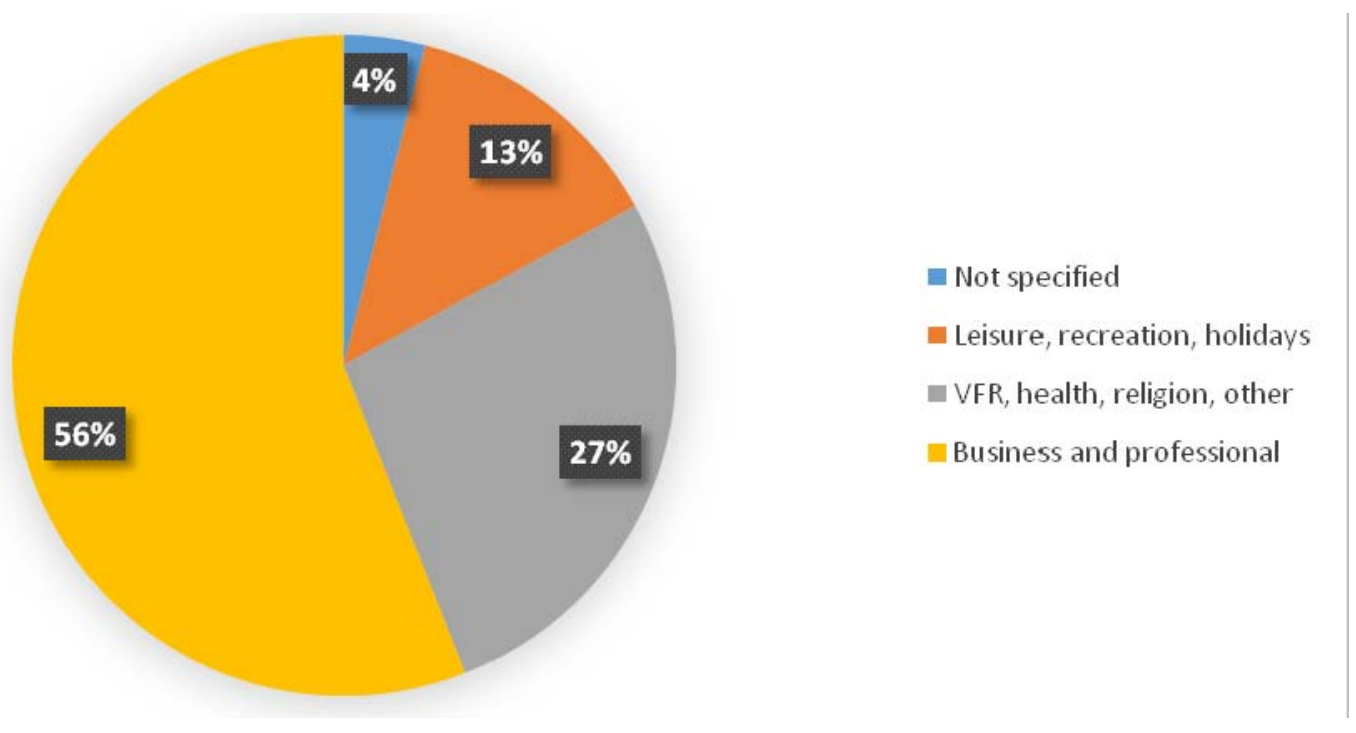

Figure 1.1. Travel distribution for the purpose of visit

The share of air travels has increased from $46 \%$ in 2000 to $58 \%$ in 2018 , while land transport has decreased from $49 \%$ to $39 \%$ in the same period (figure 1.2).

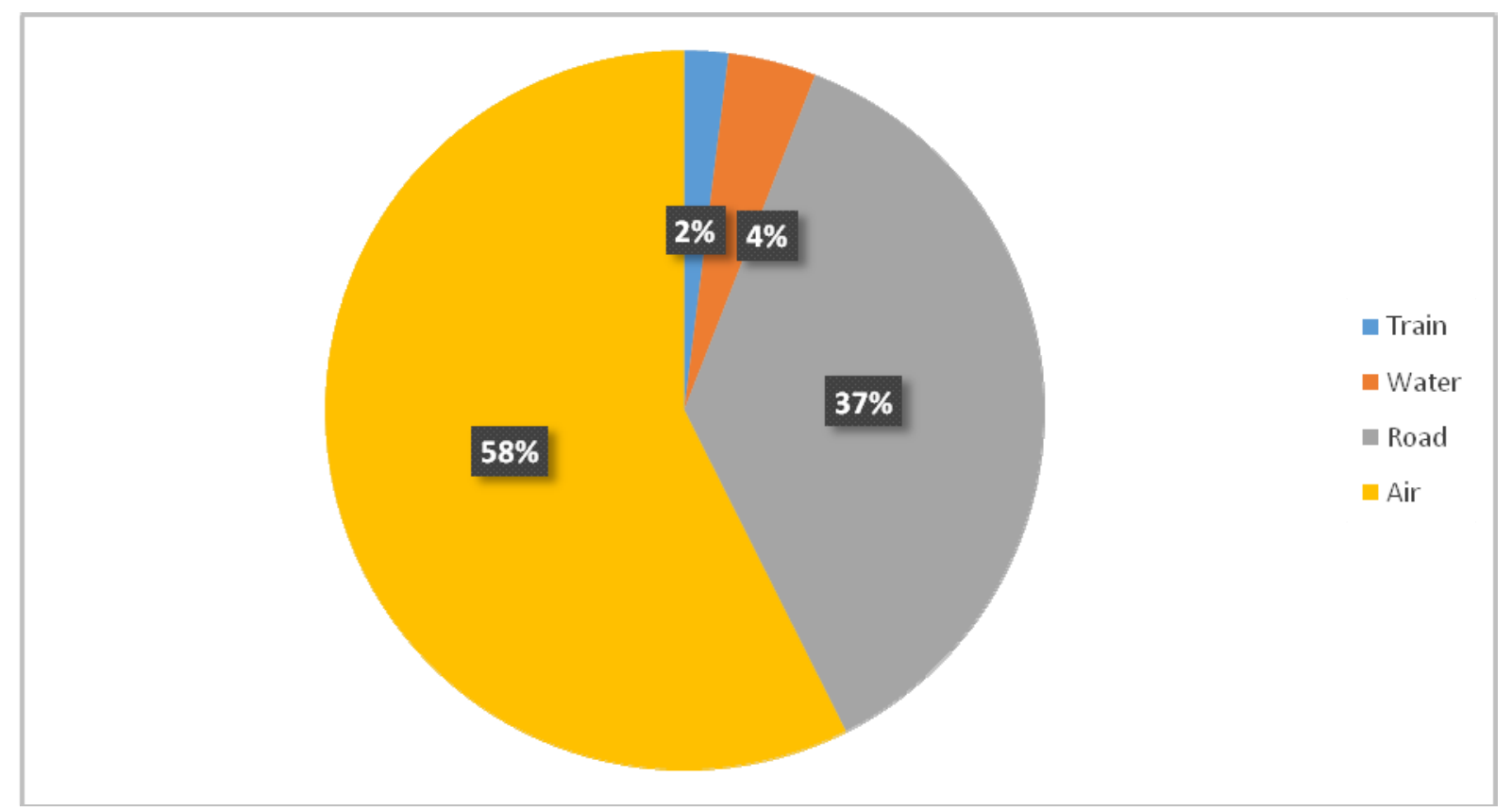

Figure 1.2. Distribution of travel by type of transport 
It should be noted that tourism grows faster than merchandise trade:

- 2018 saw an extra USD 121 billion in export revenues from international tourism (travel and passenger transport) compared to 2017;

- export earnings from international tourism are an important source of foreign revenues for many destinations in the world;

- tourism is an important component of export diversification both for emerging and advanced economies, with a strong capacity to reduce trade deficits and to compensate for weaker export revenues from other goods and services [10].

Tourism is the world's third largest export category after chemicals and fuels, and ahead of automotive products and food (figure 1.3).

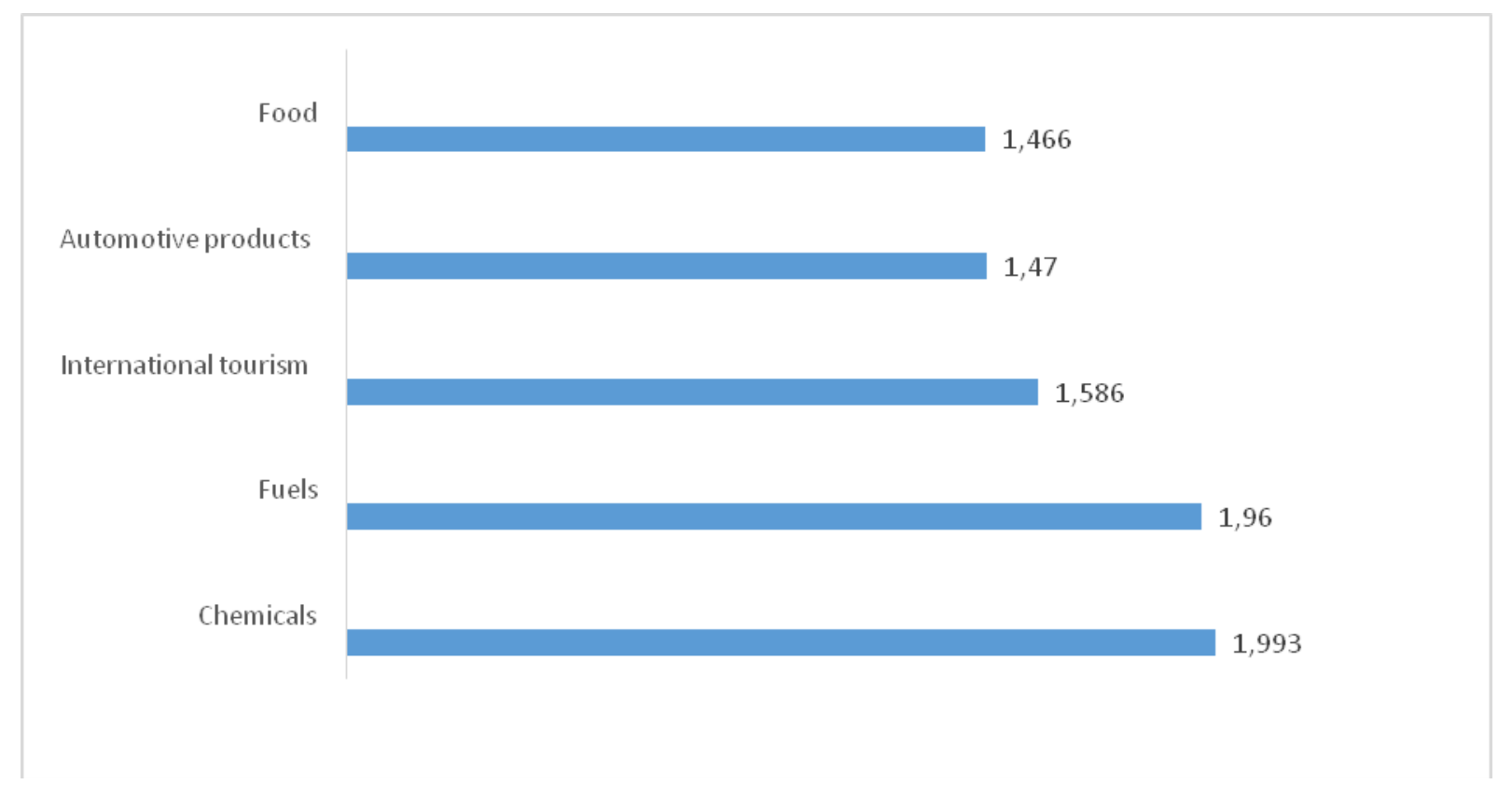

Figure 1.3. Export revenues from international tourism and merchandise exports (\% change)

As a general backdrop, connectivity continues to improve in many destinations, facilitating the diversification of source markets. With the Brexit 'dark clouds' on hold until October, travel prospects for Europe's summer season have improved. Yet, challenges remain including the tense commercial relations between the United States and China and a slowing pace of growth in many advanced economies [10].

In Ukraine, tourism is one of the few areas of business that is of great interest to both Ukrainian and foreign tourists. Tourism is a promising industry as it satisfies the ever-increasing demand of the population for quality vacations both in Ukraine and abroad and has a tendency for further growth [4]. 
Ukraine has significant tourism and recreational potential and all the prerequisites for joining the highly developed tourist countries of the world [5].

The tourism industry, as an important component of the national economy, is gaining importance and is rapidly integrating into the global tourism industry. Its development influences such spheres of economy as trade, agriculture, banking, construction, hotel business, restaurant business, transport, communication and is one of the most promising directions of structural reorientation of the economy [3].

The rapid development of the tourism industry is linked to the development of the Internet and the latest information technologies, mobile communications, biotechnology, genetically modified products, medicines, etc. [8].

According to the Tourism and Travel Competitiveness Report, Ukraine (The Travel \& Tourism Competitiveness Report 2019) has risen 10 positions over the past two years and ranked 78th in terms of total tourism competitiveness index among 140 countries [9].

The top 10 TTCI scorers remain the same. Spain is the top performer for the third consecutive report, while the United Kingdom's slight decline in competitiveness has led to it being overtaken by the United States. The top 10 are, from highest to lowest score: Spain, France, Germany, Japan, the United States, the United Kingdom, Australia, Italy, Canada and Switzerland. India (40th to 34th) had the greatest improvement over 2017 among the top $25 \%$ of all countries ranked in the report. Egypt (74th to 65th) had the best improvement among countries ranked 36 to 70, Serbia (95th to 83rd) had the largest improvement for economies ranked 71st to 105 th and Bangladesh (125th to 120th) was the most improved among the remaining $25 \%$ of scorers [9].

The Travel \& Tourism Competitiveness Report is a flagship product of the World Economic Forum's Platform for Shaping the Future of Mobility, which brings together world leaders to ensure travel and transportation systems meet 21 st century demands. This report serves as a strategic benchmarking tool for policy-makers, companies and complementary sectors to advance the future development of the T\&T sector by providing unique insight into the strengths and development areas of each country/ economy to enhance industry competitiveness. Further, it serves as a platform for multistakeholder dialogue to understand and anticipate emerging trends and risks in global travel and tourism, adapt their policies, practices and investment decisions, and accelerate new models that ensure the longevity of this important sector [9].

The index is comprised of four sub indexes, 14 pillars and 90 individual indicators, distributed among the different pillars (figure 1.4). 


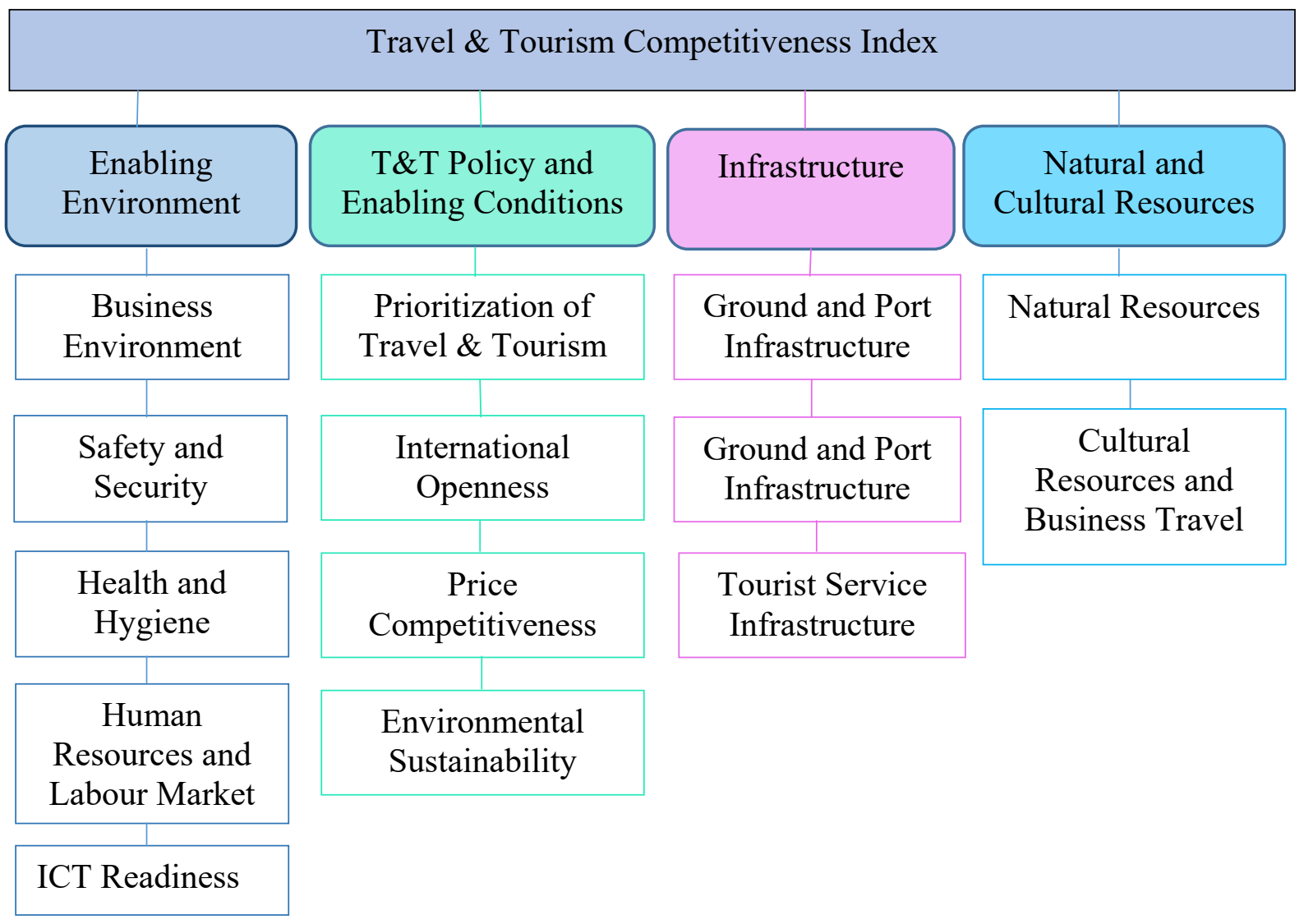

Figure 1.4. Composition Travel \& Tourism Competitiveness

Each country has its own peculiarities of tourism development, so each country has different positions on each factor. Overall, the most competitive tourist countries are Spain (5,4 points), France (5,4 points), Germany (5,4 points), Japan (5,4 points) and the United States (5,3 points) $[1,2]$.

Ukraine has 3,7 points out of 7. Surrounding our country is Jamaica, Sri Lanka, Armenia, Kazakhstan and Namibia [1, 2].

Countries such as Yemen (2,4 points), Chad (2,5 points) and Liberia (2,6 points) have the lowest index scores [1, 2].

As a result of stabilization and reconstruction, Ukraine has dramatically improved its business environment (from 124 to 103), security (from 127 to 107), international openness (from 78 to 55) and general infrastructure (from 79 to 73 ) $[6,7]$.

In 2018, according to the World Tourism Organization, the number of international tourist arrivals worldwide reached 1,4 billion, two years before it was predicted to do so. That year also marked the seventh year in a row where the growth in tourism exports $(+4 \%)$ exceeded the growth in merchandise exports $(+3 \%)$. Given this rapid pace of growth, the prediction that international arrivals will reach 1,8 billion by 2030 may be conservative $[1,10]$. 
This presents enormous potential for the sector and economies globally as travel is further democratized. Emerging economies are contributing larger proportions of travellers to this global trend and are becoming increasingly desirable as destinations as they show greater competitiveness in travel and tourism.

As has been an ongoing trend over the last four years, T\&T competitiveness continues to improve worldwide, and connectivity enabling-and enabled by-the industry remains on an upward path. The TTCI 2019 results show that air transportation, digital connectivity and international openness are advancing in a global context of growing trade tensions and nationalism. The air transport infrastructure improvements show a noticeable increase on route capacity and the number of airlines providing services in individual countries. The international openness is progressing, with lower-income economies leading the way. The digital connectivity has been bolstered by a growing number of individuals using the internet and mobile internet subscriptions, meaning more economies are now in a position to leverage the growing list of digital T\&T services.

The travel has also become, for the most part, less expensive and safer, with the Price Competitiveness pillar, for example, showing the greatest percentage increase since 2017. Lastly, T\&T is increasingly being prioritized by stakeholders around the world as measured by more favourable perceptions of government prioritization, increased industry funding and more effective marketing campaigns.

On the other hand, results also show that future demand for transportation services, especially regarding aviation, might outpace improvements in infrastructure capacity. More work also needs to be done to make sure cultural and natural assets are preserved in the face of growing tourism visits. While more environmental treaty ratifications and improvements to global average perceptions of the sustainability of $T \& T$ are encouraging signs, the continued rise in deforestation, air pollution and species endangerments point to potential gaps between policy and enforcement.

Conclusions. The analysis of the state of the tourism industry on the basis of world rankings and indices made it possible to determine Ukraine's place in the rating. The results of the research show that Ukraine, having a unique tourism potential, does not fully use it to boost the economy from tourism industry activities.

In recent years, there has been a negative trend in the number of foreign tourists in Ukraine due to the low rating of Ukraine in terms of security (107 out of 136).

However, the tourism industry of Ukraine continues to develop dynamically. The goal is now to increase tourism's share of GDP to $10 \%$, which is in line with developed countries. This should be facilitated by measures to deregulate businesses, facilitate tourist visas for citizens of different countries, and increase the number of low-cost routes to Ukraine. 


\section{REFERENCES}

1. Annual report of the World Economic Forum on Tourism and Travel. (2018). Retrieved from: http://stattur.ru/journal/20170419/.

2. Hospitality Industry Association of Ukraine. (2020). Retrieved from: http://aigu.org.ua/wef.html [in Ukrainian].

3. Humeniuk, A. I. (2015). Features of improvement of regional management of innovative activity (on the example of Ivano-Frankivsk region). Teoriia ta praktyka derzhavnoho upravlinnia v,4 (51), 104-112[ in Ukrainian].

4. Martseniuk, L. V. (2015). Problems and prospects of tourism development in Ukraine. Ekonomichnyi visnyk Natsionalnoho hirnychoho universytetu, 3, 76-82 [in Ukrainian].

5. Naidiuk, V.S. (2013). The essence and prerequisites of enterprise development. Marketynh I menedzhment innovatsii, 3, 251-263 [in Ukrainian].

6. Prokhorova, V. V., Davydova, O. Yu. \&Protsenko, V. M. (2018). Innovative strategyies for development of tourism industry as a creative form of entrepreneurial activity. Visnik ekonomiki transport I promislovosti, 63, 207-215 [in Ukrainian].

7. State Border Service of Ukraine. (2020). Retrieved from: [in Ukrainian].

8. Terebukh, A.A., Makar, O.P. \&Ilnytska, H. Ya. (2015). Problems of international tourism development in Ukraine. Molodyivchenyi, 11(2), 126-129 [in Ukrainian].

9. The Travel \& Tourism Competitiveness Report 2019 Paving the way for a more sustainable and inclusive future. Retrieved from: http://reports.weforum.org/ travel-and-tourism-competitiveness-report-2019/about-the-ttcr/.

10. World Tourism Organization (UNWTO). Retrieved from: http://www.unwto.org. 